\title{
Kitab Suci, Gereja, dan Otoritas: Harmonisasi Doktrin Kecukupan Alkitab dengan Tradisi Gereja
}

\author{
Christian Reynaldi \\ Program Studi Magister Teologi Sekolah Tinggi Teologi SAAT, Malang \\ Korespondensi: christian_reynaldi_widodo@hotmail.com
}

\begin{abstract}
Abstrak: Alkitab sebagai firman Allah merupakan sebuah kredo yang tak terbantahkan di dalam kekristenan. Salah satu implikasi dari keyakinan tersebut adalah munculnya doktrin kecukupan Alkitab. Alkitab dinyatakan cukup untuk mengajarkan manusia menuju kepada keselamatan dan ketaatan yang penuh kepada Allah. Namun, bagaimanakah kecukupan Alkitab ini didefinisikan dan diberikan batasan, sebab tampaknya tidak mungkin berteologi tanpa alat bantu apa pun. Salah satu alat bantu berteologi yang menarik perhatian penulis adalah tradisi gereja sebab sering kali dipertentangkan antara tradisi dan doktrin kecukupan Alkitab. Akan tetapi benarkah keduanya harus dipertentangkan? Tulisan ini menjawab pertanyaan harmonisasi doktrin kecukupan Alkitab dengan tradisi gereja. Penulis berargumentasi bahwa doktrin kecukupan Alkitab tidak pernah meniadakan tradisi gereja. Tradisi gereja yang mutlak harus dipakai di dalam berteologi secara Kristen adalah Rule of Faith, sebagai rangkuman dari iman kristiani yang sudah ada sejak gereja mula-mula. Tradisi gereja lainnya perlu dievaluasi terlebih dahulu penggunaannya di dalam berteologi.
\end{abstract}

Kata-kata kunci: Kecukupan Alkitab, Sola Scriptura, Tradisi, Rule of Faith, Harmonisasi

Abstract: Scripture as the Word of God is an undeniable creed in Christianity. One of many implication from this believe is the doctrine of the sufficiency of scripture. Scripture deemed sufficient enough to teach man toward salvation and full obedience unto God. Nevertheless how sufficiency of scripture is defined and confined, because it seems impossible to theologize without any supplements. One of those supplements that interest me is church tradition because people tend to contrast church tradition and doctrine of the sufficiency of scripture. However, shall two of them be contrasted? This writings will answer harmonization between doctrine of sufficiency of scripture and church tradition. I argue that doctrine of sufficiency of scripture never nulify church tradition. The absolute church tradition that must be used in theologizing as a Christian is Rule of Faith, as a summary of Christian faith since early church. Another church traditions need to be evaluated whenever they are used in theologizing.

Keywords: Sufficiency of Scripture, Sola Scriptura, Tradition, Rule of Faith, Harmonization 


\section{PENDAHULUAN}

Kaum Injili berkomitmen terhadap otoritas Alkitab sebagai penuntun yang tidak pernah salah bagi iman dan praksis kekristenan. Tidak salah jika Alan Cairns menempatkan inspirasi dan ineransi Alkitab sebagai prinsip utama yang dipertahankan oleh mereka yang menyebut dirinya Injili. ${ }^{1}$ Begitu pula pengamatan Stanley J. Grenz menunjukkan bahwa sejak pertengahan abad kedua puluh telah ada konsensus di antara kaum Injili di Amerika bahwa prinsip formal dalam gerakan Injili menuntut loyalitas terhadap Alkitab sebagai sumber yang sejati, tepercaya, final, dan otoritas dalam berteologi. ${ }^{2}$

Salah satu doktrin yang terkait dengan prinsip kaum Injili terhadap Alkitab tersebut adalah doktrin kecukupan Alkitab (sufficiency of scripture). Secara sederhana doktrin kecukupan Alkitab menyatakan bahwa Alkitab cukup untuk mengajarkan manusia menuju kepada keselamatan dan ketaatan yang penuh kepada Allah. ${ }^{3}$ Doktrin kecukupan Alkitab tidak bisa dianggap remeh sebab doktrin ini mengungkapkan salah satu dari lima prinsip penting di dalam Reformasi, yaitu sola scriptura. Sekalipun memiliki signifikansi yang penting, doktrin ini sering kali salah dipahami sebagaimana diungkapkan oleh John M. Frame, "The sufficiency of Scripture is a doctrine of immense, importance and a doctrine frequently misunderstood." 4 Oleh karena itu, ia menjelaskan doktrin ini lebih panjang daripada atribut-atribut Alkitab yang lainnya (keterbutuhan [necessity] Alkitab, kejelasan [clarity] Alkitab, dan otoritas [authority] Alkitab).

${ }^{1}$ Alan Cairns, "Evangelical," dalam Dictionary of Theological Terms (Greenville: Ambassador Emerald International, 2002), 169.

${ }^{2}$ Stanley J. Grenz, "Nurturing the Soul, Informing the Mind: The Genesis of the Evangelical Scripture Principle," dalam Evangelicals \& Scripture: Tradition, Authority, and Hermeneutics, ed. Vincent Bacote, Laura C. Miguélez, dan Dennis L. Okholm (Downers Grove: InterVarsity, 2004), 21.

${ }^{3}$ Definisi yang lebih lengkap dapat dilihat pada bagian Definisi Kecukupan Alkitab.

${ }^{4}$ John M. Frame, Systematic Theology: An Introduction to Christian Belief (Phillipsburg: P\&R, 2013), 618.
Kesalahpahaman yang terjadi di dalam doktrin kecukupan Alkitab terkait dengan peran tradisi di dalam berteologi. Sejumlah orang Kristen mengklaim bahwa mereka tidak memerlukan tradisi. Sejumlah alasan mereka kemukakan untuk menolak tradisi di dalam berteologi. ${ }^{5}$ Namun, alasan yang terkait dengan doktrin kecukupan Alkitab adalah penilaian bahwa tradisi sebagai hasil produk manusia sehingga perlu untuk dihindari. ${ }^{6}$ Kelompok ini meyakini setiap orang Kristen adalah pribadi yang otonom dan masing-masing telah diperlengkapi oleh Roh Kudus untuk mampu menafsirkan Alkitab terlepas dari tradisi gereja. Misalnya adalah kelompok Anabaptis yang menjalankan prinsip Sola Scriptura secara radikal. Bagi Kevin J. Vanhoozer mereka tidak lagi menjalankan Sola Scriptura melainkan "Solo Scriptura," yaitu hanya Alkitab satu-satunya sumber dalam berteologi-tidak ada sumber yang lain. ${ }^{7}$ Dampak yang memprihatinkan diperlihatkan salah satu ekstremis dari Anabaptis, yaitu Faustus Socinus, yang menolak sejumlah tradisi teologi yang ortodoks ditolak seperti: keilahian Kristus, Tritunggal, penebusan, dosa asal, predestinasi, dan kebangkitan tubuh. ${ }^{8}$

Lalu bagaimanakah seharusnya orang Kristen bersikap terhadap tradisi di dalam relasi dengan keyakinan mengenai kecukupan Alkitab? Apakah aplikasi yang benar terhadap doktrin kecukupan Alkitab dilakukan seperti sikap Anabaptis di atas? Ataukah ada suatu cara untuk menerima kecukupan Alkitab sekaligus menggunakan tradisi di dalam berteologi? Jika ada, bagaimanakah caranya?

${ }^{5}$ Paul J. Bagley, A Reading of Benedict Spinoza's Tractatus Theologico-Politicus, Supplements to the Journal of Jewish Thought and Philosophy (Leiden: Brill, 2008), 12.

${ }^{6}$ Alasan lainnya yaitu tradisi adalah produk masa lampau dan kuno sehingga tidak cocok bagi orang Kristen di masa kini. Manusia harus menggunakan akal pikirannya dan membuang tradisi di dalam menafsirkan Alkitab. Misalnya Barukh Spinoza yang menyatakan tradisi teologi dan agama telah mengarahkan manusia kepada iman buta yang tidak dapat diverifikasi oleh akal pikiran manusia.

${ }^{7}$ Kevin J. Vanhoozer, Biblical Authority after Babel: Retrieving the Solas in the Spirit of Mere Protestant Christianity (Grand Rapids: Brazos, 2016), 120.

${ }^{8}$ Keith A. Mathison, The Shape of Sola Scriptura (Moscow: Canon, 2001), 125. 
Semua pertanyaan tersebut dijawab di dalam artikel ini. Penulis mengajukan sebuah tesis, yaitu: doktrin kecukupan Alkitab dan tradisi tidak saling bertentangan asalkan orang-orang Kristen memahami keduanya dengan benar, serta meletakkan Alkitab dan tradisi di dalam urutan otoritas yang benar. Karena itu penting bagi penulis untuk terlebih dahulu memberikan definisi mengenai kecukupan Alkitab dan tradisi. Kemudian penulis mengemukakan relasi yang tepat di antara keduanya.

\section{DEFINISI DAN CAKUPAN DOKTRIN KECUKUPAN ALKITAB}

\section{Definisi Kecukupan Alkitab}

Wayne A. Grudem memberikan definisi yang cukup baik tentang kecukupan Alkitab. Ia mendefinisikannya sebagai berikut: "Scripture contained all the words of God he intended his people to have at each stage of redemptive history, and that it now contains everything we need God to tell us for salvation, for trusting him perfectly, and for obeying him perfectly." Dari definisi tersebut ia hendak menekankan bahwa Allah telah mewahyukan segala perkataan-Nya yang menurut-Nya cukup untuk diketahui umat-Nya, dalam bentuk Alkitab. Dalam Alkitab tercakup semua hal yang diperlukan untuk memimpin kepada keselamatan, serta kepercayaan dan ketaatan penuh padaNya (2Tim. 3:15-16). Grudem juga memberikan sebuah pengamatan yang baik mengenai kedaulatan Allah dan kecukupan Alkitab,

The doctrine of the sufficiency of Scripture does not imply that God cannot add any more words to those he has already spoken to his people. It rather implies that man cannot add on his own initiative any words to those that God has already spoken. Furthermore, it implies that in fact God has not spoken to mankind any more words which he requires us to believe or obey other than those which we have now in the Bible. ${ }^{10}$

\footnotetext{
${ }^{9}$ Wayne A. Grudem, Systematic Theology: An Introduction to Biblical Doctrine (Leicester: InterVarsity; Grand Rapids: Zondervan, 1994), 127.
}

${ }^{10}$ Ibid., 129.
Doktrin kecukupan Alkitab sesungguhnya menegaskan kedaulatan Allah. Dalam kedaulatan-Nya Allah telah menentukan hal-hal yang perlu diketahui manusia untuk memimpin mereka kepada keselamatan, yang kemudian termuat dalam Alkitab. Menambahkan ataupun mengurangi isi Alkitab sama dengan melawan kedaulatan-Nya.

Timothy Ward juga memberikan definisi kecukupan Alkitab yang baik. Ia mendefinisikannya sebagai berikut: "Because of the way in which God has chosen to relate himself to Scripture, Scripture is sufficient as the means by which God continue to present himself to us such that we can know him, repeating through Scripture the covenant promise he has brought to fulfilment in Christ." 11 Baginya kecukupan Alkitab terjadi karena Allah berkehendak untuk menciptakan relasi perjanjian yang hidup dan dinamis dengan manusia melalui Alkitab. Ia juga menambahkan bahwa kecukupan Alkitab tidak meniadakan peran Roh Kudus mengiluminasi orang Kristen untuk memahami Kitab Suci. Iluminasi Roh Kudus diperlukan sebab kecukupan Alkitab tidak mengimplikasikan seluruh teks Alkitab dengan mudah dapat dimengerti. ${ }^{12}$

Tetapi masih ada hal yang kurang jelas dari definisi di atas. Seperti apakah meyakini Alkitab cukup untuk mengajarkan keselamatan dan ketaatan kepada Allah? Dari pengertian kecukupan Alkitab secara umum di atas para teolog biasanya membedakannya lagi menjadi dua, yaitu kecukupan Alkitab secara material dan secara formal. Kecukupan Alkitab secara material menyatakan bahwa Alkitab tidak perlu dan tidak dapat ditambahkan lagi dengan apa pun. Mengapakah orang Kristen harus meyakini bahwa Allah di dalam kedaulatan-Nya tidak akan menambahi lagi Alkitab? Frame memberikan sebuah pernyataan yang tepat untuk menjawab pernyataan tersebut, "Scripture is God's testimony to the redemption he has accomplished for us. Once that redemption is finished, and the apostolic testimony to it is finished, the Scriptures are

\footnotetext{
${ }^{11}$ Timothy Ward, Words of Life: Scripture as the Living and Active Word of God (Nottingham: InterVarsity, 2009), 113.

${ }^{12}$ Ibid., 114.
} 
complete, and we should expect no more additions to them."13 Ibrani 1:1-4 menyatakan kesempurnaan keselamatan yang dikerjakan oleh Kristus sebab kini Dia "duduk di sebelah kanan Yang Mahabesar, di tempat yang tinggi." Implikasinya Perjanjian Baru (selanjutnya disingkat PB) adalah wahyu Allah tentang keselamatan yang telah sempurna dalam Kristus dan tidak perlu ditambahkan dengan apa pun. Rasul Yohanes mengutuki siapa pun yang menambahi dan mengurangi wahyu Allah (Why. 22:18; bdk. Ul. 4:2; 12:32; Ams. 30:5-6). Bukan kebetulan peringatan tersebut terletak di bagian akhir Alkitab. Hal ini menandakan bahwa seluruh Alkitab cukup untuk menjalankan fungsinya dan tidak boleh ditambahkan lagi. Namun, kecukupan Alkitab secara material tidak menjanjikan bahwa Alkitab dapat menafsirkan dirinya sendiri, atau bahwa Alkitab dapat menjadi "hakim" di dalam perdebatan penafsiran. Doktrin kecukupan Alkitab secara material hanya menyatakan Alkitab tidak dapat ditambahkan. Karena itu diperlukanlah kecukupan Alkitab secara formal.

Kecukupan formal dari Alkitab berbicara mengenai kesanggupan Alkitab untuk menafsirkan dirinya sendiri tanpa bantuan eksternal. ${ }^{14}$ Kecukupan Alkitab secara formal menjadi perdebatan yang sengit di antara Katolik Roma (KR) dan Kristen Protes$\tan (\mathrm{KP})$. KR meyakini bahwa firman Allah secara utuh terdiri dari dua jenis tradisi: tradisi tertulis dalam bentuk Alkitab dan tradisi lisan dalam bentuk pengajaran-pengajaran di luar Alkitab yang diturunkan kepada Paus dan para uskup. Alkitab perlu ditambahkan dengan tradisi dan keduanya dianggap sejajar sehingga keduanya harus diberikan penghormatan yang sama. ${ }^{15}$ Sedangkan KP dengan

\footnotetext{
${ }^{13}$ Frame, Systematic Theology, 624.

${ }^{14}$ Kevin J. Vanhoozer, The Drama of Doctrine: A Canonical-Linguistic Approach to Christian Theology (Louisville: Westminster John Knox, 2005), 157.

${ }^{15}$ Hal ini tampak dari Dokumen Konsili Vatican II tentang wahyu ilahi: "For both of them, flowing from the same divine wellspring, in a certain way merge into a unity and tend toward the same end. For Sacred Scripture is the word of God inasmuch as it is consigned to writing under the inspiration of the divine Spirit, while sacred tradition takes the word of God entrusted by Christ the Lord and the Holy
}

teguh menyatakan Alkitab mampu menafsirkan dirinya sendiri. Ini adalah prinsip hermeneutika warisan Reformator, "Kitab Suci menafsirkan Kitab Suci." Satu hal lagi yang perlu ditambahkan mengenai prinsip "Kitab Suci menafsirkan Kitab Suci" yaitu bahwa prinsip ini tidak hanya melawan KR tetapi juga Reformasi radikal atau Anabaptis. Prinsip tersebut tidak dapat dipisahkan dari Sola Scriptura yang tidak meniadakan penggunaan tradisi di dalam berteologi. ${ }^{16}$

\section{Dasar Argumentasi Doktrin Kecukupan Alkitab}

Satu hal terakhir yang perlu ditambahkan mengenai kecukupan Alkitab adalah dasar argumentasinya. Tidak mungkin meyakini sebuah doktrin tanpa dasar argumentasi. Penulis memaparkan tiga dasar argumentasi: argumentasi biblika dan historis.

\section{Argumentasi Biblika}

Dalam Alkitab tidak ada istilah "kecukupan" (sufficiency) bagi Kitab Suci, ataupun sejenisnya. Namun demikian, konsep tentang kecukupan Alkitab sesuai definisi di atas terdapat dalam sejumlah teks Alkitab. Mazmur 119:1 mengajarkan bahwa Taurat Allah cukup untuk memimpin orang kepada hidup yang tidak bercela. Teks acuan lainnya adalah 2 Timotius 3:15, "and how from childhood you have been acquainted with the sacred writings (iєpò $\gamma \rho \alpha \dot{\mu} \mu \alpha \tau \alpha)$, which are able to make you wise for salvation through faith in Christ Jesus (ESV). Dalam PB hanya sekali digunakan frasa icpò $\gamma \rho \alpha ́ \mu \mu \alpha \tau \alpha$. Josephus menggunakan frasa tersebut untuk merujuk kepada Perjanjian Lama (selanjutnya disingkat PL), demikian juga

Spirit to the Apostles, and hands it on to their successors in its full purity, so that led by the light of the Spirit of truth, they may in proclaiming it preserve this word of God faithfully, explain it, and make it more widely known. Consequently it is not from Sacred Scripture alone that the Church draws her certainty about everything which has been revealed. Therefore both sacred tradition and Sacred Scripture are to be accepted and venerated with the same sense of loyalty and reverence." "Dogmatic Constitution on Divine Revelation Dei Verbum Solemnly Promulgated by His Holiness Pope Paul VI On November 18, 1965," dalam Vatican II Documents (Vatican City Libreria Editrice Vaticana, 2011), 2.9.

${ }^{16}$ Penjelasan yang lebih komprehensif lihat bagian Doktrin Kecukupan Alkitab dan Tradisi Gereja. 
Paulus. ${ }^{17}$ Bagi Paulus PL memimpin kepada keselamatan melalui iman dalam Yesus Kristus sebab Allah sendiri yang mengilhamkan (3:16; bdk. Yak. 1:18; 1Ptr. 1:23), serta cukup untuk menjadikan orang-orang percaya, "be complete, equipped for every good work" (2Tim. 3:17; bdk. Ef. 2:10).

Lalu bagaimanakah dengan PB? Apakah PB juga memiliki otoritas yang sama dengan $\mathrm{PL}$ untuk memimpin umat Allah kepada keselamatan? Dalam 2 Petrus 3:16 secara tersirat Petrus mengenali otoritas tulisan Paulus sebagai Kitab Suci bersama-sama dengan PL (memakai kata yang sama dengan 2 Timotius 3:16 untuk Kitab Suci PL, $\gamma \rho \alpha \varphi \eta ́)$, "as he does in all his letters . . as . . other Scriptures" (ESV). ${ }^{18}$ Mengapakah PL perlu ditambahkan dengan PB? Jawabannya terletak pada wahyu Allah yang bersifat progresif ("progressive revelation"): penyataan diri Allah memperlihatkan perkembangan dari masa sebelum adanya wahyu tertulis, kemunculan PL, hingga lengkapnya wahyu tertulis melalui kemunculan PB. Allah memberikan wahyu yang cukup untuk setiap periode waktu. Setelah berdirinya gereja Allah memberikan PB untuk melengkapi PL. Pemahaman tentang Allah melalui Taurat dan kitab para nabi menjadi lebih lengkap dan sempurna (tidak perlu ditambahkan lagi) dengan adanya wahyu Allah melalui Yesus Kristus. ${ }^{19}$

${ }^{17}$ Thomas D. Lea dan Hayne P. Griffin, 1, 2 Timothy, Titus, The New American Commentary 34 (Nashville: Broadman \& Holman, 2001), 234-35.

\footnotetext{
${ }^{18}$ Gene L. Green, Jude and 2 Peter, Baker Exegetical Commentary on the New Testament (Grand Rapids: Baker, 2008), 340. Pada gereja mula-mula kata $\gamma \rho \alpha \varphi \eta ́$ mengacu kepada PL (bdk. Luk. 24:27, 32, 45; Yoh. 5:39; Rm. 1:2; 1Kor. 15:3-4; Gal. 3:8, 22; 1Tim. 5:18; 2 Tim. 3:16; 1Ptr. 2:6). Namun kemudian juga diperluas kepada ucapan-ucapan Yesus (1Tim. 5:18; bdk. Mat. 10:10; Luk. 10:7). Dalam ayat ini jelas bahwa Petrus mengimplikasikan kesejajaran tulisan-tulisan Paulus dengan PL.
}

\footnotetext{
${ }^{19}$ Stanley Grenz, David Guretzki dan Cherith Fee Nordling, "Progressive Revelation," dalam Pocket Dictionary of Theological Terms (Downers Grove: InterVarsity, 1999), 96. Bukan berarti PL memiliki otoritas yang lebih rendah ataupun menjadi tidak berfungsi lagi. Namun, wahyu yang progresif bertujuan supaya dengan demikian Alkitabdalam rupa hanya PL dan PB-cukup untuk memimpin kepada keselamatan dalam Yesus Kristus.
}

\section{Argumentasi Historis}

Bapa-bapa gereja telah menyatakan kecukupan Alkitab sebagai sumber kebenaran. Irenaeus (130-202 M), generasi kedua kekristenan setelah Rasul Yohanes, menyatakan kecukupan Alkitab sebagai fondasi iman, "We have learned from none others the plan of our salvation, than from those through whom the gospel came to us which at that time they proclaimed and afterwards by the will of God handed down to us in the Scriptures as the future foundation and pillar of our faith." ${ }^{20}$ Tertullian (155-240 M) menolak segala sesuatu yang berasal dari luar Alkitab ("extra-Scriptural"). ${ }^{21}$ Athanasius (296/98-373 M) menyatakan, "the sacred and divinely inspired Scriptures are sufficient for the exposition of the truth." ${ }^{22}$ Cyril dari Yerusalem (313-386 M) mengungkapkan bahwa sumber keselamatan tidak terdapat selain di dalam Alkitab, “. . . do not give ready belief, unless you receive from the Holy Scripture the proof of the things which I announce. The salvation in which we believe is not proved from clever reasoning, but from the Holy Scripture." 23 Agustinus (354-430 M) menyatakan bahwa ia tidak akan mengatakan hal-hal yang di luar Kitab Suci, "What more shall I teach you than what we read in the apostle [i.e. New Testament]? For holy Scripture fixes the rule for our doctrine, lest we dare to be wiser than we ought. . . . Therefore, I should not teach you anything else except to expound to you the words of the Teacher." 24

\footnotetext{
${ }^{20}$ Irenaeus, Against Heresies, 3.1.1, dikutip dalam Stephen Westerholm dan Martin Westerholm, Reading Sacred Scripture: Voices form the History of Biblical Interpretation (Grand Rapids: Eerdmans, 2016), 51. Penekanan oleh penulis.

${ }^{21}$ Tertullian, Against Hermogenes, 22 dikutip dalam Bavinck, 489.

${ }^{22}$ Athanasius, Againts Pagan I, dikutip dalam Ward, Words of Life, 107.

${ }^{23}$ Cyril of Jerusalem, Cathecital Lecture 4:17, dikutip dalam James White, "Sola Scriptura and the Early Church," dalam Sola Scriptura: The Protestant Position on the Bible, ed. Don Kistler (Technology Park: Reformation Trust, 2009), 17.
}

${ }^{24}$ Augustine, De bono viduitatis, 2, dikutip dalam White, "Sola Scriptura in Early Church," 24-25. 
John Calvin mengemukakan mengenai kecukupan formal dari Alkitab dengan menyatakan, "the highest proof of Scripture derives in general from the fact that God in person speaks in it." 25 Ia juga menyatakan tidak ada satu pun konsili mula-mula yang mendeklarasikan otoritas Alkitab berasal dari gereja. ${ }^{26}$ Pengakuan iman pasca-Reformasi juga mengajarkan hal yang sama. Dalam Westminster Confession of Faith (WCF) bab 1 butir 6 tertulis demikian,

The whole counsel of God concerning all things necessary for his own glory, man's salvation, faith and life, is either expressly set down in Scripture, or by good and necessary consequence may be deduced from Scripture: unto which nothing at any time is to be added, whether by new revelations of the Spirit, or traditions of men. Nevertheless, we acknowledge the inward illumination of the Spirit of God to be necessary for the saving understanding of such things as are revealed in the Word: and that there are some circumstances concerning the worship of God, and government of the church, common to human actions and societies, which are to be ordered by the light of nature, and Christian prudence, according to the general rules of the Word, which are always to be observed. ${ }^{27}$

Ada beberapa hal penting dari WCF, antara lain: (1) isi dari Alkitab mencakup seluruh implikasi logis darinya ${ }^{28}$ dan memiliki otoritas yang sama dengan hal-hal yang eksplisit, tanpa menambahi apa pun kepada Alkitab, ${ }^{29}$ (2) menolak adanya wahyu baru ataupun tradisi manusia (bdk. pengajaran KR) yang dapat menambahi Alkitab; (3) kecukupan Alkitab tidak meniadakan pewahyuan natural (the light of nature) dan rasio manusia (Christian

\footnotetext{
${ }^{25}$ John Calvin, Institutes of Christian Religion, Library of Christian Classics, vol. 20, ed. John T. McNeill, terj. Ford Lewis Battles (Philadelphia: Westminster, 1960), 1.7.4.

${ }^{26}$ Ibid., vol. 21, 4.9.14.

${ }^{27} \mathrm{WCF}$ 1.6. Penekanan oleh penulis.

${ }^{28}$ Misalnya istilah Tritunggal yang tidak ada di dalam Alkitab tetapi konsep-konsepnya adalah implikasi logis dari penafsiran terhadap Alkitab.
}

${ }^{29}$ Lihat Frame, Systematic Theology, 620. prudence) sebab banyak hal dalam Alkitab yang tidak diungkapkan secara eksplisit dan memerlukan deduksi yang baik; (4) penggunaan rasio dan sumber-sumber ekstrabiblikal tidak mencederai doktrin kecukupan Alkitab asalkan digunakan di bawah terang Alkitab sebagai otoritas tertinggi dan final.

\section{DEFINISI DAN CAKUPAN TRADISI GEREJA}

Mendefinisikan tradisi sangat penting sebab di sinilah letak penting untuk menjawab perdebatan antara KR dengan KP. David H. Kelsey memberikan definisi umum yang baik untuk tradisi. Baginya tradisi adalah proses gereja dalam menggunakan Kitab Suci untuk memelihara identitas Kristen. ${ }^{30}$ Serupa dengan Kelsey yang menekankan tradisi sebagai penggunaan terhadap Kitab Suci, Vanhoozer menyatakan tradisi sebagai sebuah pertunjukan komunitas orang percaya menafsirkan Kitab Suci di dalam kehidupan dan pemikiran mereka. ${ }^{31}$ Tetapi definisi dari Kelsey dan Vanhoozer belum cukup spesifik sebab setiap gereja menggunakan tradisi secara berbeda-beda, khususnya antara KR dengan KP. Definisi yang menarik diberikan oleh Heiko Augustinus Obermann. ${ }^{32}$ Obermann memberikan terminologi Tradisi I dan Tradisi II.

Dalam pengertian Tradisi I gereja menggunakan tradisi sebagai kerangka penafsiran yang benar terhadap Alkitab. Pandangan Tradisi I banyak dijumpai pada gereja mula-mula. Tradisi yang dimaksudkan adalah "Rule of Faith" ("Regula Fidei" atau "Aturan Iman"). Michael F. Bird mendefinisikan Rule of Faith sebagai "general outline of Christian beliefs that circulated in the second-century church." 33 Meskipun disebut sebagai general outline, Rule of Faith tidak berbentuk pernyataan-pernyataan

\footnotetext{
${ }^{30}$ David H. Kelsey, Proving Doctrine, dikutip dalam Vanhoozer, Drama of Doctrine, 153.

${ }^{31}$ Ibid., 152.

${ }^{32}$ Heiko Augustinus Obermann, The Harvest of Medieval Theology: Gabriel Biel and Late Medieval Nominalism (Cambridge: Harvard University Press, 1963), 390-93.

${ }^{33}$ Michael F. Bird, Evangelical Theology: A Biblical and Systematic Introduction (Grand Rapids: Zondervan, 2013), 66.
} 
melainkan sebuah narasi, sebagaimana tampak dalam tulisan Irenaeus. Kredibilitas Rule of Faith tidak diragukan sebagai penyimpan tradisi apostolik tentang Yesus Kristus. Vanhoozer menyatakan bahwa Rule of Faith menyediakan pembacaan yang integratif antara PL dan PB, yaitu pembacaan secara kristosentris dan eskatologis. Rule of Faith dapat dikatakan sebagai ringkasan metanarasi Allah, yaitu sejarah penebusan Allah. ${ }^{34}$ Sedemikian pentingnya Rule of Faith sehingga Rule of Faith menjadi penjaga orang Kristen dari ajaran-ajaran sesat. ${ }^{35}$

Lalu bagaimana dengan Tradisi II? Tradisi II menyatakan bahwa firman Allah memiliki dua sumber yang berbeda, sebagaimana yang diyakini oleh KR, yaitu tradisi lisan dan Alkitab. Tradisi lisan diturunkan kepada Paus dan para uskup secara kolektif sebagai penerus dari Rasul Petrus, sang pemimpin gereja. ${ }^{36}$ Meskipun secara kolektif diberikan kepada magisterium (Paus dan para uskup), penentu yang penuh, tertinggi, dan universal atas gereja adalah Paus sendiri. ${ }^{37}$ Secara historis muncul Tradisi II dimulai sejak zaman Basil dari Kaisarea (330-370 M). ${ }^{38}$ Basil mengklaim sejumlah tradisi di luar Alkitab sebagai tradisi

\footnotetext{
${ }^{34}$ Vanhoozer menggunakan istilah metadrama, yaitu kisah alam semesta dan perjanjian yang bertemu pada Yesus Kristus (Drama of Doctrine, 205).

${ }^{35}$ Kathryn Greene-McCreight, "Rule of Faith," dalam Dictionary for Theological Interpretation, ed. Kevin J. Vanhoozer (Grand Rapids: Baker, 2005), 703-04. Bdk. Bird, Evangelical Theology, 67.

36"Dogmatic Constitution on the Church Lumen Gentium Solemnly Promulgated by His Holiness Pope Paul VI On November 21, 1964," dalam Vatican II Documents (Vatican City: Libreria Editrice Vaticana, 2011), 3.25. "For then the Roman Pontiff is not pronouncing judgment as a private person, but as the supreme teacher of the universal Church, in whom the charism of infallibility of the Church itself is individually present, he is expounding or defending a doctrine of Catholic faith. The infallibility promised to the Church resides also in the body of Bishops, when that body exercises the supreme magisterium with the successor of Peter."
}

${ }^{37}$ Ibid., 3.22. "But the college or body of bishops has no authority unless it is understood together with the Roman Pontiff. ... as Vicar of Christ and pastor of the whole Church, the Roman Pontiff has full, supreme and universal power over the Church. And he is always free to exercise this power."

${ }^{38}$ Obermann, Harvest of Medieval Theology, 369-70. yang diturunkan secara lisan oleh para rasul dan memiliki otoritas yang sama dengan Alkitab. Kemudian dilanjutkan dengan pernyataan Agustinus bahwa dirinya tidak akan percaya kecuali di bawah otoritas gereja Katolik. ${ }^{39}$ Ward melihat bahwa KR salah memahami perkataan Agustinus. Ia tidak bermaksud untuk mengesahkan tradisi gereja memiliki otoritas yang terpisah dan setara dengan Alkitab, melainkan gereja sebagai pemberita dan pengajar Alkitab. ${ }^{40}$

Satu lagi tambahan terhadap definisi Obermann adalah "Tradisi 0" yang dikemukakan oleh Alister McGrath. Tradisi 0 adalah sebuah bentuk penolakan secara total terhadap tradisi dan lebih memprioritaskan penafsiran pribadi, “'Tradition 0' placed the private judgment of the individual above the corporate judgment of the Christian church concerning the interpretation of Scripture. It was a recipe for anarchy-and, as the history of the radical Reformation sadly demonstrates, that anarchy was not slow to develop." 41

\section{DOKTRIN KECUKUPAN ALKITAB DAN TRADISI GEREJA}

Setelah menjelaskan definisi dari kecukupan Alkitab dan tradisi gereja kini tiba saatnya penulis mengusulkan relasi antara doktrin kecukupan Alkitab dan tradisi gereja. Untuk mempertunjukkan relasi tersebut maka penulis akan menjawab pertanyaan berikut: (1) Apakah doktrin kecukupan Alkitab meniadakan penggunaan tradisi Alkitab?; (2) Bagaimanakah relasi yang tepat antara Alkitab sebagai satu-satunya sumber yang memimpin kepada keselamatan dan ketaatan dengan tradisi gereja?; dan (3) Tradisi seperti apakah yang perlu dipertahankan di dalam berteologi?

\section{Penggunaan Tradisi: Sebuah Kepastian di dalam Berteologi}

Herman Bavinck menyatakan keniscayaan tradisi di dalam berteologi, "Therefore, a

\footnotetext{
${ }^{39}$ Ibid. 370.

${ }^{40}$ Ward, Words of Life, 144-45.

${ }^{41}$ Mathison, Shape of Sola Scriptura, 127.
} 
tradition is needed that preserves the connectedness between Scripture and the religious life of our time. Tradition in its proper sense is the interpretation and application of the eternal truth in the vernacular and life of the present generation. Scripture without such a tradition is impossible." 42 Tradisi menghubungkan kebenaran Alkitab yang kekal dengan situasi orang percaya yang partikular. Stephen R. Holmes menjelaskan bahwa penggunaan tradisi adalah sebuah pengakuan orang Kristen tentang keterikatannya terhadap sejarah ("historical locatedness"). ${ }^{43}$ Ia menggunakan doktrin penciptaan yang disandingkan dengan doktrin inkarnasi, dan doktrin persekutuan dengan Kristus ("union with Christ," "in Christ") untuk menjelaskan keterikatan tersebut.

Pertama, Holmes menyatakan bahwa sejarah adalah ciptaan Allah yang baik. Agustinus di dalam Confession menyatakan bahwa sejarah dunia adalah bagian dari kejatuhan sehingga manusia perlu dibebaskan darinya. Sejarah membawa manusia jauh daripada kesempurnaan yang tidak dibatasi oleh waktu. ${ }^{44}$ Namun demikian, bukti dalam Alkitab menyatakan tidak selalu demikian. Kejadian 1-2 menyatakan bahwa segala sesuatu yang Allah ciptakan adalah baik. Inkarnasi membuktikan bahwa Anak Allah mengizinkan diri-Nya untuk terikat dengan sejarah. Lukas mencatat bahwa Yesus bertumbuh seiring dengan sejarah yang bergerak maju (Luk. 2:52). Sejumlah pengajaran Yesus juga merupakan tradisi Yahudi. ${ }^{45}$

${ }^{42}$ Herman Bavinck, Reformed Dogmatics, vol. 1, Prolegomena, ed. John Bolt, terj. John Vriend (Grand Rapids: Baker Academic, 2003), 493.

${ }^{43}$ Stephen R. Holmes, Listening to the Past: The Place of Tradition in Theology (Grand Rapids: Baker, 2002), 6.

${ }^{44}$ Augustine, The Confessions of St. Augustine, terj. E.B. Pusey (Oak Harbor, 1996), XI.11.

${ }^{45}$ Contohnya adalah perbandingan antara Yesus Kristus dengan Guru Kebenaran dalam Gulungan Laut Mati pada saat akhir zaman. Terdapat kesejajaran antara 1QH (The Thanksgiving Hymns) 15:12 ("or all who attack me You will condemn to judgment, so that in me You might divide between the righteous and the ungodly") dengan Matius 25:32 ("he will separate people one from another") dan Yohanes 12:48 ("The one who rejects me and does not receive my word has a judge; on the last day the word that I have spoken will serve as judge"). Larry R. Helyer, Exploring Jewish Literature of the Second Temple Period: A Guide for New Testament Students (Downers Grove: InterVarsity,
Melalui inkarnasi Yesus menyatakan bahwa Dia memberikan diri-Nya terikat sebagai orang Yahudi keturunan Daud untuk dapat menggenapi PL. Karena keterikatan terhadap sejarah tidak perlu dipandang negatif demikian juga keterikatan terhadap tradisi, "I have thus far sought to argue that, because of the doctrine of creation, historical locatedness is something good. The tradition we inherit is a part of our location in history, and so in doing theology is necessary to relate to the tradition." 46

Dalam argumen yang kedua untuk menyatakan keniscayaan tradisi dalam berteologi Holmes menyatakan bahwa frasa yang umum dalam surat-surat Paulus, "in Christ," bukan hanya sekadar ketergabungan seorang Kristen dengan orang Kristen di seluruh abad dan tempat (doktrin gereja yang tak kasat mata ${ }^{47}$ ). Satu orang Kristen memiliki relasi yang khusus dengan orang Kristen lainnya, baik yang pernah ia temui maupun belum (karena terpisah secara geografis ataupun terpisah karena waktu). Relasi tersebut adalah sebuah relasi antar-anggota tubuh dengan Kristus sebagai Kepalanya (Rm. 12; 1Kor. 12; Ef. 4). ${ }^{48}$

Dengan menggunakan tradisi gereja di dalam berteologi setidaknya terdapat tiga manfaat. Pertama, menghargai kesaksian para pendahulu iman yang telah memperjuangkan imannya. Kisah mereka menjadi teladan bagi orang Kristen di masa kini dan masa mendatang, "They thus become examples to be loved with and studied, whose writings amplify without adding to the teachings of Scripture in just the same way as the lives of the Saints amplify without adding to the example of Christ." 49 Kedua, tradisi dapat menyediakan kerangka penafsiran yang baik seperti pada penjelasan Rule of Faith di atas. Sebuah penafsiran yang sama sekali tidak didukung oleh satu tradisi mana pun patut dicurigai. Ketiga, penggunaan tradisi juga berguna di dalam apologetika.

2002), 263. Sekalipun ada kesejajaran, perbedaan antara keduanya juga tidak boleh diabaikan.

\footnotetext{
${ }^{46}$ Holmes, Listening to the Past, 17.

${ }^{47}$ Grudem, Systematic Theology, 855-57.

${ }^{48}$ Holmes, Listening to the Past, 25-26.

${ }^{49}$ Ibid., 29.
} 
Berdasarkan penjelasan di atas tampak bahwa para Reformator menggunakan tradisi gereja mula-mula untuk menunjukkan bahwa apa yang mereka lakukan selaras dengan tradisi tersebut. Doktrin kecukupan Alkitab, khususnya bahwa Alkitab tidak dapat ditambahi dan Alkitab dapat menafsirkan dirinya sendiri, adalah doktrin yang berasal dari tradisi gereja abad permulaan. Patut diingat pula bahwa ancaman yang dihadapi para Reformator adalah Anabaptis yang sama sekali menolak penggunaan tradisi. ${ }^{50}$

\section{Penggunaan Tradisi: Sebuah Penafsiran yang Relatif terhadap Alkitab yang Absolut}

Sebelumnya telah dipaparkan sejumlah alasan penggunaan teologi yang tak terhindarkan. Pertanyaannya sekarang adalah relasi seperti yang berlaku antara tradisi dan Alkitab? Apakah terdapat tradisi yang menjadi norma di dalam pembentukan Alkitab? Sejumlah teolog berargumen bahwa Rule of Faith adalah standar penentu di dalam proses kanonisasi PB sehingga bukan hanya penafsiran Alkitab yang tidak dapat dipisahkan dari gereja, melainkan juga penafsiran Alkitab ditentukan oleh komunitas penafsirnya. Contoh yang paling nyata adalah Craig D. Allert. Ia berpendapat, "[i]t was this Rule of Faith againts which everything was measured in second centuryeven the writings of the developing New Testament." ${ }_{51}$ Karena itu bagi Allert pernyataan Alkitab sebagai satu-satunya sumber tertinggi dalam gereja harus ditolak, ". . . and appeal to the 'Bible' as the early church's sole rule for faith and life is anachronistic." 52 Implikasinya, gereja menjadi satu-satunya penafsir yang berotoritas di atas Alkitab dan Alkitab tidak dapat menafsirkan dirinya sendiri.

Vanhoozer dengan tegas menolak pandangan tersebut. Vanhoozer mengakui manfaat Rule of Faith dalam memberikan prasuposisi yang baik dalam menafsirkan Alkitab, ${ }^{53}$ dan bahwa

\footnotetext{
${ }^{50}$ Bird, Evangelical Theology, 69-70.

${ }^{51}$ Craig D. Allert, A High View of Scripture? The Authority of the Bible and the Formation of New Testament Canon (Grand Rapids: Baker, 2007), 79.

${ }^{52}$ Ibid., 145.

${ }^{53}$ Vanhoozer, Drama of Doctrine, 204.
}

Rule of Faith sendiri tidak menambahkan makna apa pun terhadap Alkitab sebab ia adalah ringkasan pengajaran para rasul tentang Yesus Kristus..$^{54}$ Namun, persoalannya Rule of Faith sendiri secara teologis bukanlah berada di atas Alkitab melainkan sebuah ringkasan semata. ${ }^{55}$ Sebuah ringkasan tidak lebih besar daripada tulisan yang diringkasnya, justru tulisan tersebut yang lebih berotoritas. Otoritas Rule of Faith berlaku hanya jika ia sesuai dengan Kitab Suci. Fungsi utama dari Rule of Faith adalah menjadi sebuah sebuah prasuposisi, dan prasuposisi tersebut bukan hanya sekadar berfungsi di dalam menafsirkan secara kristosentris. Fungsi utama dari Rule of Faith adalah menyatakan bahwa Alkitab dapat menafsirkan dirinya sendiri, "The ultimate purpose of the Rule [of Faith] is to let Scripture interpret Scripture. Here is the end of the matter: the Rule [of Faith] rules but is itself ruled (by the canon); the canonical script rules but is not itself ruled." 56

Menurut penulis ada sedikit kekurangan dalam argumen dari Vanhoozer. Sejarah gereja menunjukkan bahwa kanon belum benar-benar stabil hingga abad keempat. Memang benar sudah ada pengakuan terhadap tulisan-tulisan para rasul sebagai tulisan yang berotoritas layaknya PL (2Ptr. 3:1516). ${ }^{57}$ Namun, tidak sedikit juga beredar kitab-kitab palsu, juga ditambah oleh muncul bidat Marcion. Untuk itu diperlukan kriteria untuk mengenali kitab-kitab kanonik, yang salah satunya adalah Rule of Faith. ${ }^{58}$ Dalam

${ }^{54}$ Bird menyatakan Rule of Faith berkembang menjadi Pengakuan Iman Nicea dan Chaceldon. Dengan melihat kepada isi dari ketiga kredo tersebut jelas bahwa ketiganya tidak bertentangan dengan Alkitab.

${ }^{55}$ Vanhoozer, Drama of Doctrine, 206.

${ }^{56}$ Ibid., 207.

${ }^{57}$ Lihat tabel dalam Lee Martin McDonald tentang perjalanan kanonisasi yang panjang dan tidak langsung beres pada abad pertama. Lee Martin McDonald, Formation of the Bible: the Story of Church's Canon (Peabody: Hendrickson, 2012), 12.

${ }^{58}$ Ada empat kriteria apostolisitas (apakah penulisnya adalah rasul?), ortodoksi (apakah sesuai dengan Rule of Faith?), kepurbakalaan (apakah dapat ditanggalkan pada masa apostolik?), dan katolisitas (apakah diterima oleh gereja-gereja secara mayoritas?). Lihat Michael F. Bird, What Christian Ought to Believe: An Introduction 
konteks dapat dikatakan bahwa kitab-kitab kanonik adalah "produk" gereja. Dan secara kronologis tampaknya Rule of Faith ada terlebih dahulu daripada kanon. Namun tidak demikian. Rasul-rasul sudah menulis tulisantulisan berotoritas sejak abad pertama dan jemaat mengenalinya berdasarkan tradisi kerasulan. Lukas segera menulis Injil Lukas dan Kisah Para Rasul karena banyak kisah yang simpang siur mengenai Yesus (bdk. Luk. $1: 1-4$; Kis. 1:1-3).

Akan tetapi fakta bahwa Rule of Faith digunakan sebagai salah satu kriteria dalam proses kanonisasi tidak dapat dipungkiri. Penulis tetap pada posisi bahwa dalam pengertian tertentu dapat dikatakan bahwa Rule of Faith adalah "produk" gereja. Bukan berarti penulis menyatakan bahwa makna Alkitab ditentukan oleh gereja, dan Alkitab adalah produk gereja. Karena pada akhirnya semuanya adalah anugerah dari Allah Tritunggal. Berdasarkan alasan teologis-teologis berikut penulis mencoba menyintesiskan pandangan Vanhoozer dan Allert:

1. Pada konteks gereja mula-mula belum memiliki PB, tradisi lisan apostolik_yang tersimpan dalam Rule of Faith-adalah anugerah dari Roh Kudus. Kesadaran gereja mula-mula terhadap kitab-kitab kanonik adalah karya Roh Kudus, "The church's recognition of a writing as Scripture derives not from its natural common sense but from its supernatural common sense, a spiritual intuition of Word of God. . . . The Spirit's role is not to go beyond Scripture, adding new words, but to enable the church to perceive and respond to the words that are already there." ${ }^{59}$ Dengan demikian Alkitab tetap bersifat self-testifying.

2. Bapa-bapa gereja dan Reformator memiliki keyakinan yang mantap bahwa penafsiran yang tidak sesuai dengan Rule of Faith adalah penafsiran yang keliru, "Where the Rule of Faith is not followed, the Reformers deem that reading of Scripture as inadequate and therefore as not adhering to

to Christian Doctrine through the Apostles' Creed (Grand Rapids: Zondervan, 2016), 36.

${ }^{59}$ Vanhoozer, Drama of Doctrine, 199. the literal sense. ${ }^{60}$ Keyakinan atas Rule of Faith didasari atas sifatnya yang merangkumkan pengajaran para rasul. Pengajaran para rasul sendiri mendapatkan otoritas dari Yesus Kristus, sang Firman Allah yang diutus Bapa dan yang bergantung pada Roh Kudus (bdk. Mat. 3:16; Luk. 1:35; 4:1). Dan pada saat Roh Kudus menyaksikan kembali segala perkataan Yesus (Yoh. 14:26). Jadi pengajaran para rasul yang menjadi "dasar" dari Rule of Faith" pada dirinya sendiri bukanlah karya gereja melainkan karya Allah Tritunggal.

Mengenai sikap gereja terhadap Tradisi II tidak perlu dikatakan banyak. Segala jenis tradisi-tradisi gereja yang tidak terdapat di dalam Alkitab sudah jelas harus ditolak. Tidak ada satu pun tradisi gereja yang dapat menyaingi Alkitab. Tradisi bisa salah dan tradisi adalah buatan manusia yang terbatas dan telah jatuh dalam dosa. Kitab Suci mampu menampilkan "illocutionary acts"-nya (makna penulis) sendiri yang menuntut "perlocutionary acts" (respons dan tindakan ketaatan dari komunitas orang percaya). Perlocution (penafsiran, tradisi gereja) selalu bergantung kepada illocution (makna ilahi Alkitab ${ }^{61}$ ). ${ }^{62}$

\section{Penggunaan Tradisi: Kesesuaian dengan Alkitab}

Tradisi seperti apakah yang baik? Tentu saja itu adalah tradisi yang sesuai Alkitab, tradisi yang merupakan hasil iluminasi Roh Kudus sehingga gereja menyaksikan pesan-pesan dalam Kitab tentang Yesus Kristus. John Calvin mengemukakan alasan mengapa ia mengikuti pengakuan iman Nicea tentang Tritunggal, "But when it is so often asserted in Scripture that there is one God, and further, when Christ is called so often the true and eternal God, one with the Father-what else are

\footnotetext{
${ }^{60}$ Greene-McCreight, "Rule of Faith,” 704.
}

${ }^{61}$ Maksud Allah di dalam Alkitab tidaklah berbeda dengan maksud penulis kitab. Nicholas Wolterstorff berpendapat, "I see no reason to think that it proceeds differently when it is God who appropriates the discourse-by-inscription of some human being. . . ." (Divine Discourse: Philosophical Reflection on the Claim that God Speaks [Cambridge: Cambridge University Press, 1995], 204).

${ }^{62}$ Vanhoozer, Drama of Doctrine, 192-93. 
the Nicene fathers doing when they declare them of one essence but simply expounding the real meaning of Scripture?"63 Baginya kedua pengakuan iman tersebut membuat eksplisit apa yang implisit tentang Yesus Kristus. Demikian juga dengan konsili-konsili mulamula (seperti: Nicea, Konstantinopel, Efesus I, Chalcedon, dsb.) bukan karena otoritas gereja melainkan karena selaras dengan Alkitab, "For they contain nothing but the pure and genuine exposition of Scripture." 64

\section{KESIMPULAN}

Doktrin kecukupan Alkitab didasarkan pada fakta bahwa Akitab adalah firman Allah yang dinapaskan oleh-Nya. Implikasinya adalah Alkitab dapat menafsirkan dirinya sendiri dan tidak memperoleh makna dari tradisi gereja mana pun. Sekalipun dalam pengertian tertentu dapat dikatakan bahwa Alkitab adalah "produk" gereja namun dalam pembuatannya tersebut semuanya berasal dari anugerah Allah Tritunggal, dan bukan otonomi gereja sendiri.

Doktrin kecukupan Alkitab tidak pernah meniadakan peran tradisi. Namun perlu dijelaskan bahwa tradisi berada di bawah Alkitab, termasuk Rule of Faith yang selama ini diakui kredibel. Karena itu gereja perlu memilah mana tradisi yang sejati dan mana yang bukan. Tradisi yang sejati adalah penafsiran yang relatif dan harus selalu dikoreksi agar senantiasa sesuai dengan Alkitab sebab Alkitab adalah otoritas final dan tertinggi di dalam hidup manusia.

\section{DAFTAR KEPUSTAKAAN}

Allert, Craig D. A High View of Scripture? The Authority of the Bible and the Formation of New Testament Canon. Grand Rapids: Baker, 2007.

Augustine. The Confessions of St. Augustine. Diterjemahkan oleh E.B. Pusey. Oak Harbor, 1996.
Bagley, Paul J. A Reading of Benedict Spinoza's Tractatus Theologico-Politicus. Supplements to the Journal of Jewish Thought and Philosophy. Leiden: Brill, 2008.

Bavinck, Herman. Reformed Dogmatics. Vol. 1. Prolegomena. Diedit oleh John Bolt. Diterjemahkan oleh John Vriend. Grand Rapids: Baker Academic, 2003.

Bird, Michael F. Evangelical Theology: A Biblical and Systematic Introduction. Grand Rapids: Zondervan, 2013.

- What Christian Ought to Believe: An Introduction to Christian Doctrine through the Apostles' Creed. Grand Rapids: Zondervan, 2016.

Cairns, Alan. "Evangelical." Dalam Dictionary of Theological Terms, 169-70. Greenville: Ambassador Emerald International, 2002.

Calvin, John. Institutes of Christian Religion. Library of Christian Classics. vol. 20. Diedit oleh John T. McNeill. Diterjemahkan oleh Ford Lewis Battles. Philadelphia: Westminster, 1960.

Frame, John M. Systematic Theology. Phillipsburg: P\&R, 2013.

Green, Gene L. Jude and 2 Peter. Baker Exegetical Commentary on the New Testament. Grand Rapids: Baker, 2008.

Greene-McCreight, Kathryn. "Rule of Faith." Dalam Dictionary for Theological Interpretation, diedit oleh Kevin J. Vanhoozer, 703-04. Grand Rapids: Baker, 2005.

Grenz, Stanley J. "Nurturing the Soul, Informing the Mind: The Genesis of the Evangelical Scripture Principle.” Dalam Evangelicals \& Scripture: Tradition, Authority, and Hermeneutics, diedit oleh Vincent Bacote, Laura C. Miguélez, dan Dennis L. Okholm, 19-41. Downers Grove: InterVarsity, 2004.

\footnotetext{
${ }^{63}$ Institutes, vol. 21, 4.8.16

${ }^{64}$ Ibid., 4.9.8
} 
Grenz, Stanley J., David Guretzki, dan Cherith Fee Nordling. "Progressive Revelation." Dalam Pocket Dictionary of Theological Terms, 96. Downers Grove: InterVarsity, 1999.

Grudem, Wayne A. Systematic Theology: An Introduction to Biblical Doctrine. Leicester: InterVarsity; Grand Rapids: Zondervan, 1994.

Helyer, Larry R. Exploring Jewish Literature of the Second Temple Period: A Guide for New Testament Students. Downers Grove: InterVarsity, 2002.

Holmes, Stephen R. Listening to the Past: The Place of Tradition in Theology. Grand Rapids: Baker, 2002.

Lea, Thomas D., dan Hayne P. Griffin. 1, 2 Timothy, Titus. The New American Commentary 34. Nashville: Broadman \& Holman, 2001.

Mathison, Keith A. The Shape of Sola Scriptura. Moscow: Canon, 2001.

McDonald, Lee Martin. Formation of the Bible: the Story of Church's Canon. Peabody: Hendrickson, 2012.

Obermann, Heiko Augustinus. The Harvest of Medieval Theology: Gabriel Biel and Late Medieval Nominalism. Cambridge: Harvard University Press, 1963.
Pope Paul VI. "Dogmatic Constitution on the Church Lumen Gentium: Solemnly Promulgated by His Holiness Pope Paul VI On November 21, 1964.” Dalam Vatican II Documents. Vatican City: Libreria Editrice Vaticana, 2011.

. "Dogmatic Constitution on Divine Revelation: Dei Verbum Solemnly Promulgated by His Holiness Pope Paul VI On November 18, 1965." Dalam Vatican II Documents. Vatican City: Libreria Editrice Vaticana, 2011.

The Westminster Confession of Faith. Ed. ke-3. Atlanta: Committee for Christian Education and Publications, 1990.

Vanhoozer, Kevin J. The Drama of Doctrine: A Canonical-Linguistic Approach to Christian Theology. Louisville: Westminster John Knox, 2005.

Biblical Authority after Babel: Retrieving the Solas in the Spirit of Mere Protestant Christianity. Grand Rapids: Brazos, 2016.

Ward, Timothy. Words of Life: Scripture as the Living and Active Word of God. Nottingham: InterVarsity, 2009.

Wolterstorff, Nicholas. Divine Discourse: Philosophical Reflection on the Claim that God Speaks. Cambridge: Cambridge University Press, 1995. 